\title{
The Effect of Adding Soaked Sweet Lupine and Chickpea Flour on Physical and Chemical Properties of Cake. \\ Abdel-Gawwad, A. . ${ }^{1}$; Rania E. El-Gammal ${ }^{1}$; E. A. Abdelrasoul ${ }^{2}$ and B. A. Barakat ${ }^{2}$ \\ 1. Food Industries Dept., Fac. of Agric., Mansoura Univ. \\ 2. Food Technology Res. Inst., Agric. Res. Center, Giza, Egypt.
}

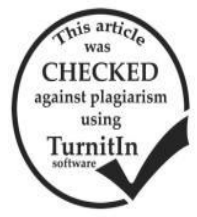

\begin{abstract}
Pan cake was prepared by replacing wheat flour with both of soaked sweet lupine and chickpea flour at the levels of 10 , $15,20 \%$ and mixture from both of them at the ratio of (1:1). Ten processed cake samples were sensory evaluated. Results indicated that cake samples which prepared by $20 \%$ soaked sweet lupine, $20 \%$ soaked chickpea, $10 \%$ soaked chickpea, $10 \%$ soaked sweet lupine $+10 \%$ soaked chickpea and control samples recorded the highest score for color, taste, odour, texture, appearance and overall acceptability, so these samples were selected for different chemical and physical analysis. Results for chemical properties showed that crude protein being $22.38,18.15,16.38$ and $20.64 \%$, crude fat 27.19, 28.55, 27.91 and $27.15 \%$, total carbohydrate $48.97,51.37,35.85$ and $50.37 \%$ and ash content $1.46,1.93,1.86$ and $1.48 \%$ for abovementioned selected prepared cake samples, respectively.Texture profile analysis showed that replacement of wheat flour by both of soaked sweet lupine and chickpea flour decrease firmness, gumminess, chewiness and resilience of processed cake samples, also replacement of wheat flour with soaked sweet lupine and chickpea flour decrease the freshness period of processed cakes. Finally, from obtained results, it could be concluded that replacement of wheat flour by soaked sweet lupine and chickpea flour increase protein and minerals content in processed cake samples. Soaked sweet lupine and chickpea flour could be uses as a good source of natural antioxidants, especially phenolic compounds.
\end{abstract}

Keywords: Soaked sweet lupine flour, soaked chickpea flour, cake, texture, antioxidants and phenolic compounds.

\section{INTRODUCTION}

Beginning of modern civilization, consumption of various bakery and confectionary products is the demand of time due to change in food habits of the people. Cake one of the relished and palatable baked products prepared from wheat flour, sugar, oil, baking powder, egg and orange.

Cake prepared by the replacement of wheat flour with some legumes flour such as sweet lupine and chickpeas flour for nutritionally balanced cake. Sweet lupine is an economically and agriculturally valuable plant and a good source of proteins, fat, dietary fiber, minerals and vitamins (Martinez-villaluenga et al., 2006 and Gulewicz et al., 2008). Chickpea is one of the most important legume crops in the world, with a world production of 10.4 million tons (FAO/STAT, 2011). Chickpea are valuable source of calories, protein, minerals, fibers and minor component of potential health benefits (Vega et al., 2010). Sweet lupine and chickpea seeds consider as hypoglycemic foods which decrease blood glucose levels and hypocholesterolemic foods which decrease levels of cholesterol in blood (ElHadidy, 2009).

It has a high amount of unsaturated fatty acids, especially oleic and linoleic.

Sweet lupine and chickpea flour, with their protein content, minerals and fiber contents are ideal ingredient for improving the nutritional value and quality of cakes.

This research was aimed to study the effect of partial replacement of wheat flour by soaked sweet lupine and chickpea flour on chemical, physical properties and quality of pan cakes.

\section{MATERIALS AND METHODS}

\section{Materials:}

sweet lupine and chickpeas:

sweet lupine Giza 1 (Lupinus albus L.) and chickpea Giza 1 (Cicer arietinum L.) were obtained from Agricultural Res. Center, Crops field Institute, Kafr El-Sheikh City, Egypt, season (2013).

\section{Other ingredients:}

Wheat flour (72\%), sunflower oil, sugar, eggs, baking powder and orange, were obtained from local market of Kafr El-Sheikh City, Egypt.

Methods:

Preparing of soaked sweet lupine and chickpea seeds:

Both of sweet lupine and chickpea seeds were cleaned, removed foreign matters by hand picking followed by sieving. Seeds were soaked in tap water with $(1: 10 \mathrm{w} / \mathrm{v})$ for 12 hours at $25^{\circ} \mathrm{C}$. (El-Hadidy, 2009). Soaked seeds were dried in oven (Mechanical Dehydrator, HI-Tech Equipments, India) at $60^{\circ} \mathrm{C}$ for 24 hours, then milled using a laboratory electronic mill (BRAWN, Model 2001 DL, Germany). (Lattanzio et al., 1989). After that dried sweet lupine and chickpeas flour were kept in polyethylene bags at room temperature until used

Formulation of cake samples using different ratios of sweet lupine and chickpea flour:

The basic formulation of pan cake and composite of flour cakes are outlined in Table (1).

Cake processing:

Cake samples were prepared by replacing wheat flour with different levels of composite flour in the basic formulation of cake (Table 1) as described in the methods of A.A.C.C. (2002). Wheat flour, soaked sweet lupine or chickpea flour, whole fresh eggs, baking powder, oil and orange were mixed in mixing machine for 20 min using a mixture at low speed (145 rpm). Prepared mixtures were poured into circular baking pans with diameters of 22-24 cm and a depth of 5-6 cm backed in an automatic oven at $170-190^{\circ} \mathrm{C}$ for $25-35$ min. Baked cakes were removed immediately and left to cool for 1-1.5 hr at room temperature. Then packaged in polyethylene bags until further evaluation and analysis were carried out. 
Table (1): Formulation of different cake samples (100 $\mathrm{g}$ flour basis)

\begin{tabular}{lcccccccccc}
\hline $\begin{array}{l}\text { Ingredient } \\
(\mathbf{g})\end{array}$ & $\begin{array}{c}\text { Control } \\
\text { No.1 }\end{array}$ & $\mathbf{N o . 2}$ & $\mathbf{N o . 3}$ & $\mathbf{N o . 4}$ & $\mathbf{N o . 5}$ & $\mathbf{N o . 6}$ & No.7 & No.8 & No.9 & No.10 \\
\hline Wheat flour & 100 & 80 & 85 & 90 & 80 & 85 & 90 & 80 & 85 & 90 \\
S.S.L.F.* & 0 & 20 & 15 & 10 & 0 & 0 & 0 & 0 & 0 & 0 \\
S.C.F.** & 0 & 0 & 0 & 0 & 20 & 15 & 10 & 0 & 0 & 0 \\
S.S.L.F.+ S.C.F. & 0 & 0 & 0 & 0 & 0 & 0 & 0 & $10+10$ & $7.5+7.5$ & $5+5$ \\
Sugar & 55 & 55 & 55 & 55 & 55 & 55 & 55 & 55 & 55 & 55 \\
Oil & 57 & 57 & 57 & 57 & 57 & 57 & 57 & 57 & 57 & 57 \\
Baking powder & 3.6 & 3.6 & 3.6 & 3.6 & 3.6 & 3.6 & 3.6 & 3.6 & 3.6 & 3.6 \\
Egg & 10 & 10 & 10 & 10 & 10 & 10 & 10 & 10 & 10 & 10 \\
Orange & 50 & 50 & 50 & 50 & 50 & 50 & 50 & 50 & 50 & 50 \\
\hline
\end{tabular}

*S.S.L.F.: soaked sweet lupine flour **S.C.F.: soaked chickpea flour.

\section{Gross chemical composition:}

Moisture, ash and crude fat were determined according to A.O.A.C. (2000).

Crude protein was estimated by determining the total nitrogen content using micro-kjeldahl method according to the A.O.A.C. (2000). Crude protein was calculated by multiplying total percentage of nitrogen by factor (5.7)

Total carbohydrates was calculated by subtracting the differences from initial weight of the sample according to James (1995) as follows:

Total carbohydrates $\%=100-[\%$ crude protein + $\%$ crude fat $+\%$ ash on dry weight basis $]$.

Gross chemical composition were determined at Agricultural Res. Center, Food Technology Res. Institute, Kafr El-Sheikh City, Egypt.

\section{Determination of phenolic compounds:}

Phenolic compounds were determined by (HPLC) according to the method of Goupy et al. (1999) at Agric. Res. Cent., Food Technol. Res.. Inst., Giza, Egypt as follows: $5 \mathrm{~g}$ of sample were mixed with methanol and centrifuged at $1000 \mathrm{rpm}$ for $10 \mathrm{~min}$ and the supernatant was filtered through a $0.2 \mathrm{Mm}$ Millipore membrane filter then 1-3 mL was collected in a vial for injection into HPLC Agilent 1200 series equipped with autosampling injector, solvent degasser, ultraviolet (UV) detector set at $330 \mathrm{~nm}$ and quaternary HP pump (series 1100). The column temperature was maintained at $35^{\circ} \mathrm{C}$. Gradient separation was carried out with methanol and acetonitrile as mobile phase at flow rate of $1 \mathrm{ml} / \mathrm{min}$. Phenolic acid standard from Sigma Co. were dissolved in a mobile phase in injected into HPLC. Retention time and peak area were used to calculation of phenolic compounds concentration by the data analysis of HEWLLET Packard Software.

Staling of cake samples:

Cake samples, were tested by alkaline water retention capacity determination, according to the method of Yamazaki (1953) as modified by Kitterman and Rubenthaler (1971). Five grams of each formula (placed into dry plastic centrifuge tube of $50 \mathrm{ml}$ capacity), $25 \mathrm{ml}$ of $\mathrm{NaHCO}_{3}$ solution (8.4 g sodium bicarbonate dissolved in 1 liter of distilled water) were added. The tube was stoppered and shaked until all meal was wet, then the mixture was left for 20 minute with shaking every 5 minutes. The contents were then centrifuged at $2500 \mathrm{rpm}$ for 15 minutes. The supernatant was descanted and the precipitate was left for 10 minutes at $45^{\circ} \mathrm{C}$ (to get rid of free water). The experiment was duplicated and average gain of the two runs was recorded to give the alkaline water retention capacity in percent.

The method used for fresh cake samples at zero time, then cake samples were stored for (2) and (4) days at room temperature.

Texture profile analysis:

Physical properties were recorded by texture profile analyzer.

Texture measurements of samples were carried out with universal testing machine (Cometech, Btype, Taiwan) provided with software. $35 \mathrm{~mm}$ diameter compression disc was used. Two cycles were applied, at a constant cross head velocity of $1 \mathrm{~mm} / \mathrm{s}$, to $30-50 \%$ of sample depth, then returned.

From the resulting force-time, i.e. firmness $(\mathrm{N})$, gumminess $(\mathrm{N})$, chewiness $(\mathrm{N})$, adhesiveness (N.S), cohesiveness, springiness and resilience were calculated from the TPA graphic. according to Bourne (2003). at Food Technology Res. Inst., Agric. Res. Center, Giza, Egypt.

\section{Sensory evaluation of cake samples:}

Organoleptic test was determined according to Twillman and White (1988). Cake samples were served to panel test of (10) judges to evaluate color, odour, taste, texture, appearance and overall acceptability using hedonic scale from (10) to (1) as described by Smith et al. (1973).

Cake samples were organoleptically evaluated at Food Technology Res. Inst., Kafr El-Sheikh City, Egypt.

Statistical analysis of sensory evaluation of cake samples:

Data were analyzed using SPSS by one way analysis of variance (ANOVA). A multiple comparison of treatment means was performed by Duncan's new multiple range test according to Steell and Torrie (1980), significance of the differences was defined as $\mathrm{P}<0.05$.

\section{RESULTS AND DISCUSSION}

\section{Chemical composition of sweet lupine and chickpea flour (on dry weight basis):}

Chemical composition of two legumes soaked sweet lupines and chickpeas flour were studied. Results found in Table (2) revealed that soaked sweet 
lupine and soaked chickpea flour can be considered as rich source for crude protein which contained 23.60 and $11.70 \%$ respectively.

In addition it could be noticed that moisture content was $12.23 \%$ in soaked sweet lupine and $11.54 \%$ in soaked chickpea flour. The results showed that total carbohydrates was higher in soaked chickpea flour
$(66.09 \%)$, while soaked sweet lupine flour contained $48.02 \%$. Mean while crude fat were 12.63 and $8.26 \%$ in soaked sweet lupine and soaked chickpea flour respectively, finally ash are recorded $3.52 \%$ in soaked sweet lupine flour and $2.41 \%$ in soaked chickpea flour. These results were nearly in accordance with Allam (2001) and Erbas et al. (2005).

Table (2): Chemical composition of soaked sweet lupine and soaked chickpea flour.

\begin{tabular}{lcc}
\hline Components \% & Soaked sweet lupine flour & Soaked chickpea flour \\
\hline Moisture & 12.23 & 11.54 \\
Crude fat & 12.63 & 8.26 \\
Crude protein & 23.60 & 11.70 \\
Ash & 3.52 & 2.41 \\
Total carbohydrate * & 48.02 & 66.09 \\
\hline
\end{tabular}

*Total carbohydrate was calculated by difference

Phenolic compounds of soaked sweet lupine and chickpea flour (on dry weight basis):

High-performance liquid chromatography (HPLC) used for separation and identification of phenolic compounds in both types of the two legumes (soaked sweet lupine and chickpea flour). It was contained 22 phenolic compounds.
Phenolic compounds composition of soaked sweet lupine and soaked chickpea flour were presented in Table (3).The results cleared that soaked sweet lupine and soaked chickpea flour are a good source for phenolic compounds especially; syringic, catechol, epicatechein, P.OH benzoic, benzoic, salycilic and pyrogallol.

Table (3): Identification of phenolic compounds of soaked sweet lupine and soaked chickpea flour (mg/100g).

\begin{tabular}{lcc}
\hline Phenolic compounds & $\begin{array}{c}\text { Soaked sweet lupine flour } \\
(\mathbf{m g} / \mathbf{1 0 0 g})\end{array}$ & $\begin{array}{c}\text { Soaked chickpea flour } \\
(\mathbf{m g} / \mathbf{1 0 0 g})\end{array}$ \\
\hline Syringic & 47233.88 & 33419.98 \\
Gallic & 22.08 & 191.00 \\
Pyrogallol & 1215.66 & 11284.90 \\
4-Aminobenzoic & 385.04 & 1793.89 \\
Protocatechuic & 260.69 & 1685.07 \\
Catcchein & 567.37 & 722.76 \\
Chlorogenic & 85.47 & 329.97 \\
Catechol & 3947.36 & 431.05 \\
Epicatechein & 1753.33 & 862.56 \\
P.OH.benzoic & 12079.33 & 349.01 \\
Caffeic & 128.03 & 72.24 \\
Vanillic & 196.54 & 100.59 \\
p-Coumaric & 774.57 & 238.18 \\
Ferulic & 106.13 & 89.07 \\
Iso-ferulic & 302.64 & 93.32 \\
Ellagic & 224.76 & 201.64 \\
A-coumaric & 749.96 & 39.42 \\
Benzoic & 2098.69 & 271.53 \\
Salycilic & 2005.46 & 162.94 \\
Coumarin & 35.45 & 120.59 \\
Cinnamic & 13.20 & 41.04 \\
\hline
\end{tabular}

Data showed that soaked sweet lupine flour contain high levels of syringic (47233.88 mg/100 g), followed by P.OH benzoic (12079.33 mg/100 g), catechol (3947.36 mg/100 g) and benzoic (2098.69 $\mathrm{mg} / 100 \mathrm{~g})$. On the other hand, soaked sweet lupine flour have lower levels of vanillic $(196.54 \mathrm{mg} / 100 \mathrm{~g})$, caffeic $(128.03 \mathrm{mg} / 100 \mathrm{~g})$, chlorogenic $(85.47 \mathrm{mg} / 100 \mathrm{~g})$ and ferulic $(106.13 \mathrm{mg} / 100 \mathrm{~g})$. Also, it contains trace of gallic, coumarin and cinnamic, while soaked chickpea flour contain higher amount of syringic (33419.98 $\mathrm{mg} / 100 \mathrm{~g})$, followed by pyrogallol $(11284.9 \mathrm{mg} / 100 \mathrm{~g})$, 4-amino benzoic $(1793.89 \mathrm{mg} / 100 \mathrm{~g})$, and protocatechuic $(1685.07 \mathrm{mg} / 100 \mathrm{~g})$, and lower levels of catechein $(722.76 \mathrm{mg} / 100 \mathrm{~g})$, catechol $(431.05 \mathrm{mg} / 100$ g), P.OH.benzoic (349.01 mg/100 g), and gallic (191 $\mathrm{mg} / 100 \mathrm{~g})$, beside, it contains trace of cinnamic, Acoumarin, ferulic, iso-ferulic, vanillic and caffeic.

Most of these compounds are widely distributed in nature and have been shown to possess antioxidative properties (Partt and Hudson. 1990, Ho et al, 1992 and Kanner et al., 1994). The presence of phenolic hydroxyl groups increases the antioxidative activity of phenolic acids, while methoxylation of hydroxyl groups causes a decrease in its activity (Marinova and yanishlieva 1992) 
Sensory evaluation of processed cake samples with different ratios of soaked sweet lupine and chickpea flour:

The influence of replacing wheat flour with soaked sweet lupine and chickpea flour at the levels of $10,15,20 \%$ and mixture between them at (1:1) were statistically analyzed and illustrated in Table (4).

Processed cake samples were sensory evaluated for different properties namely color, taste, odour, texture, appearance and overall acceptability.
Mean score of color, taste, odour, texture, appearance, overall acceptability and total score preference were presented in Table (4).

Data showed that the highest scores being 9, 8.8, 8.6, 8.7, 8.6 and 9 for color, taste, odour, texture, appearance and overall acceptability, respectively were recorded for cake sample No.1 followed by processed cake samples No. 5, 8, 2, 7 and 6 .

While other cake samples, namely No. 3, 4, 9 and 10 recorded the lowest scores for the same properties.

Table (4): Sensory evaluation of processed cake samples with different ratios soaked sweet lupine and chickpea flour:

\begin{tabular}{|c|c|c|c|c|c|c|c|c|}
\hline No. & Treatment & $\begin{array}{l}\text { Color } \\
(\mathbf{1 0})\end{array}$ & $\begin{array}{l}\text { Taste } \\
(10)\end{array}$ & $\begin{array}{l}\text { adour } \\
(\mathbf{1 0})\end{array}$ & $\begin{array}{l}\text { Texture } \\
\quad(10)\end{array}$ & $\begin{array}{l}\text { Appearance } \\
\text { (10) }\end{array}$ & $\begin{array}{c}\text { Overall } \\
\text { Acceptability } \\
(\mathbf{1 0}) \\
\end{array}$ & Total \\
\hline 1 & Control & $\begin{array}{r}9 \pm \\
0.94 \mathrm{a}\end{array}$ & $\begin{array}{l}8.8 \pm \\
0.79 \mathrm{a}\end{array}$ & $\begin{array}{c}8.6 \pm \\
0.84 \mathrm{a}\end{array}$ & $\begin{array}{l}8.7 \pm \\
0.95 \mathrm{a}\end{array}$ & $\begin{array}{c}8.6 \pm \\
0.84 \mathrm{a}\end{array}$ & $\begin{array}{c}9 \pm \\
0.82 \mathrm{a}\end{array}$ & $\begin{array}{l}52.7 \pm \\
0.60 \mathrm{a}\end{array}$ \\
\hline 2 & $\begin{array}{l}20 \% \text { soaked sweet lupine } \\
\text { flour }\end{array}$ & $\begin{array}{c}7.3 \pm \\
0.82 \mathrm{bc}\end{array}$ & $\begin{array}{l}7.4 \pm \\
1.26 \mathrm{ab}\end{array}$ & $\begin{array}{l}7.8 \pm \\
1.23 \mathrm{ab}\end{array}$ & $\begin{array}{l}7.5 \pm \\
0.85 \mathrm{~b}\end{array}$ & $\begin{array}{l}7.5 \pm \\
0.97 \mathrm{bc}\end{array}$ & $\begin{array}{l}7.8 \pm \\
0.63 b\end{array}$ & $\begin{array}{l}45.3 \pm \\
0.77 \mathrm{bc}\end{array}$ \\
\hline 3 & $\begin{array}{l}15 \% \text { soaked sweet lupine } \\
\text { flour }\end{array}$ & $1.0 \frac{7}{\mathrm{c}} \mathrm{c}$ & $1.2 \pm \frac{7 \pm}{b c}$ & $\begin{array}{l}6.9 \pm \\
1.37 \mathrm{bc}\end{array}$ & $1.25 \mathrm{f} b \mathrm{bc}$ & $\begin{array}{c}7.1 \pm \\
1.10 \mathrm{bcd}\end{array}$ & $\begin{array}{c}7.2 \pm \\
1.23 \mathrm{bc}\end{array}$ & $\begin{array}{l}42.2 \pm \\
1.08 \mathrm{bcd}\end{array}$ \\
\hline 4 & $\begin{array}{l}10 \% \text { soaked sweet lupine } \\
\text { flour }\end{array}$ & $\begin{array}{l}7.3 \pm \\
0.82 \mathrm{bc}\end{array}$ & $\begin{array}{c}7.2 \pm \\
0.79 \mathrm{bc}\end{array}$ & $\begin{array}{l}6.6 \pm \\
1.17 \mathrm{c}\end{array}$ & $\begin{array}{c}6.9 \pm \\
0.74 \mathrm{bc}\end{array}$ & $\begin{array}{c}6.8 \pm \\
0.79 \mathrm{~cd}\end{array}$ & $\begin{array}{c}6.8 \pm \\
0.79 \mathrm{bc}\end{array}$ & $\begin{array}{c}41.6 \pm \\
0.68 \mathrm{~cd}\end{array}$ \\
\hline 5 & $\begin{array}{l}20 \% \text { soaked chickpea } \\
\text { flour }\end{array}$ & $0.8 \frac{8 \pm}{2} \mathrm{~b}$ & $\begin{array}{c}7.9 \pm \\
0.56 \mathrm{ab}\end{array}$ & $\begin{array}{c}7.8 \pm \\
0.92 \mathrm{ab}\end{array}$ & $\begin{array}{c}7.9 \pm \\
0.74 \mathrm{ab}\end{array}$ & $\begin{array}{l}7.7 \pm \\
0.67 \mathrm{bc}\end{array}$ & $\begin{array}{l}7.8 \pm \\
0.92 \mathrm{~b}\end{array}$ & $\begin{array}{l}47.1 \pm \underline{t} \\
0.56 \mathrm{~b}\end{array}$ \\
\hline 6 & $\begin{array}{l}15 \% \text { soaked chickpea } \\
\text { flour }\end{array}$ & $\begin{array}{l}7.5 \pm \\
0.71 \mathrm{bc}\end{array}$ & $\begin{array}{l}7.5 \pm \\
1.08 \mathrm{bc}\end{array}$ & $\begin{array}{l}7.2 \pm \\
0.92 \mathrm{bc}\end{array}$ & $\begin{array}{l}7.2 \pm \\
1.32 \mathrm{bc}\end{array}$ & $\begin{array}{c}7.3 \pm \\
0.67 \mathrm{bcd}\end{array}$ & $\begin{array}{l}7.6 \pm \\
0.84 b\end{array}$ & $\begin{array}{c}44.3 \pm \\
0.63 \mathrm{bc}\end{array}$ \\
\hline 7 & $\begin{array}{l}10 \% \text { soaked chickpea } \\
\text { flour }\end{array}$ & $\begin{array}{c}7.6 \pm \\
0.7 \mathrm{bc}\end{array}$ & $0.8 \stackrel{7 \pm}{2} \mathrm{bc}$ & $\begin{array}{c}7.3 \pm \\
0.82 \mathrm{bc}\end{array}$ & $\begin{array}{l}7.6 \pm \\
1.07 \mathrm{~b}\end{array}$ & $\begin{array}{l}7.4 \pm \\
0.52 \mathrm{bc}\end{array}$ & $\begin{array}{l}7.5 \pm \\
0.70 \mathrm{~b}\end{array}$ & $\begin{array}{l}44.4 \pm \\
0.59 \mathrm{bc}\end{array}$ \\
\hline 8 & $\begin{array}{l}10 \% \text { soaked sweet lupine } \\
\text { flour } \pm 10 \% \text { soaked } \\
\text { chickpea flour }\end{array}$ & $1.05 \mathrm{~b}$ & $\begin{array}{l}7.5 \pm \\
1.43 \mathrm{bc}\end{array}$ & $\begin{array}{c}7.8 \pm \\
1.23 \mathrm{ab}\end{array}$ & $\begin{array}{c}7.9 \pm \\
0.87 \mathrm{ab}\end{array}$ & $\begin{array}{c}7.8 \pm \\
1.13 \mathrm{ab}\end{array}$ & $\begin{array}{l}7.8 \pm \\
1.13 \mathrm{~b}\end{array}$ & $\begin{array}{l}46.8 \pm \\
1.01 \mathrm{~b}\end{array}$ \\
\hline 9 & $\begin{array}{l}7.5 \% \text { soaked sweet lupine } \\
\text { flour } \pm 7.5 \text { soaked } \\
\text { chickpea flour }\end{array}$ & $\begin{array}{l}6.8 \pm \\
1.13 \mathrm{c}\end{array}$ & $\begin{array}{l}6.6 \pm \\
1.65 \mathrm{c}\end{array}$ & $\begin{array}{l}6.7 \pm \\
1.16 \mathrm{c}\end{array}$ & $\begin{array}{l}6.4 \pm \\
1.58 \mathrm{c}\end{array}$ & $\begin{array}{l}6.4 \underline{+} \\
1.43 \mathrm{~d}\end{array}$ & $\begin{array}{l}6.5 \pm \\
1.58 \mathrm{c}\end{array}$ & $\begin{array}{l}39.4 \pm \\
1.20 \mathrm{~d}\end{array}$ \\
\hline 10 & $\begin{array}{l}5 \% \text { soaked sweet lupine } \\
\text { flour } \pm 5 \% \text { soaked } \\
\text { chickpea flour }\end{array}$ & $\begin{array}{c}7.4+\underline{+} \\
0.84 \overrightarrow{b c}\end{array}$ & $\begin{array}{c}7.4+\underline{+} \\
0.97 \overline{b c}\end{array}$ & $\begin{array}{c}7.6 \pm \\
0.70 \mathrm{ab}\end{array}$ & $\begin{array}{c}6.8 \pm \\
1.03 \mathrm{bc}\end{array}$ & $\begin{array}{c}7.0 \pm \\
1.05 \mathrm{bcd}\end{array}$ & $\begin{array}{c}7.4+\underline{+} \\
0.84 \mathrm{bc}\end{array}$ & $\begin{array}{c}43.6 \pm \\
0.74 \mathrm{bcd}\end{array}$ \\
\hline
\end{tabular}

Values followed by the same letter in column are not significantly different by Duncan's multiple range test $(\mathrm{P}<0.05)$.

From Table (4), no significant differences were observed among samples No. 5 and No. 8 in color, taste, odour, texture, appearance, overall acceptability and total score at $\mathrm{P}<0.05$. Also, there were no great significantly differences between samples No. 2 and 7 at $\mathrm{P}<0.05$. Generally, processed cake samples No. 1,5, 8, 2, 7 which recorded the highest score for color, taste, odour, texture, appearance and overall acceptability were selected and packaged in polyethylene bags until subsequent analysis.

Chemical composition of processed cake samples with different ratios of soaked sweet lupine and chickpea flour ( $\%$ on dry weight basis):

Chemical composition of processed cake using sweet lupine and chickpea flour were presented in Table (5).

Data in Table (5) indicated that moisture content of the control sample was $42.76 \%$. The percentages of moisture were $41.87,39.39,40.86$ and $40.65 \%$ for processed cake samples No. 1, 2, 3, and 4, which contained $20 \%$ soaked sweet lupine, 20\% soaked chickpea, $10 \%$ soaked chickpea and $10 \%$ soaked sweet lupine $+10 \%$ soaked chickpea, respectively.

Crude fat content of control sample being $22.52 \%$, while 27.19, 28.55, 27.91 and $27.15 \%$ were recorded for processed cake samples No. 1, 2, 3 and 4, respectively.

The ash content of control sample was $1.30 \%$ ,while there were no observed differences in ash content of processed cake samples No. 1, 2, 3 and 4 being 1.46, $1.93,1.86$ and $1.48 \%$, respectively.

Results in Table (5) also indicated that control cake sample which contained $100 \%$ wheat flour have $15.07 \%$ crude protein, comparing with other processed cake samples No. 1, 2, 3 and 4 being 22.38, 18.15, 16.38 and $20.64 \%$, respectively.

Total carbohydrates were high in control cake sample $(61.11 \%)$, comparing with processed cake samples No. 1, 2, 3, and 4 being 48.97, 51.37, 35.85 and $50.37 \%$, respectively, naturally due to the high wheat flour content in control sample. 
Table (5): Gross chemical composition of processed cake samples with different ratios of soaked sweet lupine and chickpea flour (\% on dry weight basis).

\begin{tabular}{lccccc}
\hline \multirow{2}{*}{ Chemical constitutes } & Control & \multicolumn{3}{c}{ Processed cake using sweet lupine and chickpea flour. } \\
& sample & No. (1) & No. (2) & No. (3) & No. (4) \\
\hline Moisture (\%) & 42.76 & 41.87 & 39.39 & 40.86 & 40.65 \\
Crude fat (\%) & 22.52 & 27.19 & 28.55 & 27.91 & 27.15 \\
Ash (\%) & 1.30 & 1.46 & 1.93 & 1.86 & 1.48 \\
Crude protein (\%) & 15.07 & 22.38 & 18.15 & 16.38 & 20.64 \\
*Total carbohydrates (\%) & 61.11 & 48.97 & 51.37 & 35.85 & 50.37 \\
\hline
\end{tabular}

No.(1): $20 \%$ soaked sweet lupine flour

No. (2): $20 \%$ chickpea flour

No. (3): 10\% soaked chickpea flour

No. (4): $10 \%$ soaked sweet lupine flour + $10 \%$ soaked chickpea flour

* Total carbohydrates was calculated by differences.

On the other hand, obtained results revealed that replacing wheat flour with soaked sweet lupine and chickpea flour increased crude fat, ash contents and crude protein content, while total carbohydrates decreased in processed cake samples comparing with control sample.

The results showed that replacing wheat flour with soaked sweet lupine flour at the level of $20 \%$ increased protein content to $22.38 \%$ when compared with those cake samples replacing wheat flour with soaked chickpea flour at the same level $(18.15 \%)$, this may be due to soaked sweet lupine which have high content of crude protein in comparing with soaked chickpea flour. These results are in agreement with those obtained by Rahut et al. (2012).

Physical properties of processed cake samples with different ratios of soaked sweet lupine and chickpea flour:

The effect of replacement wheat flour with soaked sweet lupine and chickpea flour on physical properties of processed cake samples such as firmness, cohesiveness, chewiness, springiness and resilience which recorded by texture profile analyzer was presented in Table (6).

Table (6): Physical properties of processed cake samples with different ratios of soaked sweet lupine and chickpea flour.

\begin{tabular}{lccccc}
\hline Properties (N) & Control & \multicolumn{4}{c}{ Processed cake using sweet lupine and chickpea flour } \\
& sample & No. (1) & No. (2) & No. (3) & No. (4) \\
\hline Firmness & 1.37 & 1.18 & 0.93 & 1.18 & 1.08 \\
Cohesiveness & 0.649 & 0.326 & 0.535 & 0.516 & 0.365 \\
Gumminess & 0.888 & 0.385 & 0.498 & 0.609 & 0.394 \\
Chewiness & 0.624 & 0.167 & 0.282 & 0.364 & 0.170 \\
Springiness & 0.702 & 0.435 & 0.566 & 0.599 & 0.430 \\
Resilience & 0.409 & 0.183 & 0.277 & 0.319 & 0.235 \\
\hline
\end{tabular}

No.(1): $20 \%$ soaked sweet lupine flour

No. (2): $20 \%$ chickpea flour

No. (3): 10\% soaked chickpea flour

No. (4): $10 \%$ soaked sweet lupine flour $+10 \%$ soaked chickpea flour

N. : Newton

The results cleared that control cake sample was higher in all physical properties parameters than other processed cake samples (No. 1, 2, 3 and 4).

Control cake sample recorded $1.37,0.649,0.888$ ,0.624, 0.702 and $0.409(\mathrm{~N})$ for firmness ,cohesiveness, Gumminess, chewiness, springiness and resilience , respectively.

On the other hand, there is no clear differences were recorded between processed cake samples No. 1, 2,3 , and 4 for all physical properties.

Firmness of processed cake samples No. 1, 2, 3, and 4 were $1.18,0.93,1.18$ and $1.08(\mathrm{~N})$, and cohesiveness were $0.326,0.535,0.516$ and $0.365(\mathrm{~N})$, while Gumminess were $0.385,0.498,0.609$ and 0.394 (N), also Chewiness were $0.167,0.282,0.364$ and 0.170 (N). Springiness were $0.435,0.566,0.599$, and 0.430 (N) and resilience were $0.183,0.277,0.319$ and 0.235 (N), respectively. These results were nearly in accordance with those given by Yousif and Saffa (2014).
Staling rate\% of processed cake samples with different ratios of soaked sweet lupine and chickpea flour:

Table (7) showed the effect of replacing wheat flour with both of soaked sweet lupine and chickpea flour on staling rate $\%$ of cake samples at zero time and cake samples stored for 2 and 4 days at room temperature.

From Table (7) control cake sample exhibited the highest freshness values during storage period comparing with other processed cake samples.

Processed cake samples No.1 and 3 showed the highest freshness values and highest staling rate \% compared with other processed cake samples.

Data in the same table indicated that staling rate \% of control sample and different processed cake samples No. 1, 2, 3, and 4 were decreased prolonged storage periods.

Data showed that staling rate \% of control cake sample at zero time, after 2 days and after 4 days was 
$151.60 \%, 133.19 \%$ and $102.83 \%$, respectively. While, staling rate $\%$ of processed cake sample No. 1 at zero time, after 2 days and after 4 days was 136.87, 124.28\% and $98.34 \%$, respectively. Staling rate\% of processed cake samples No. 2, 3 and 4 at zero time were $119.60 \%$, $148 \%$ and $129.96 \%$, respectively, while after 2 days were $102.96 \%, 110.45 \%$ and $106.52 \%$, respectively. But, after 4 days were $90.32 \%, 99.47 \%$ and $90.55 \%$, respectively.
The data in showed that staling rate $\%$ of control sample No. 3 was high $(148.00 \%)$, followed by sample No.1 (136.87\%), sample No. 4 (129.96\%) and sample No.2 $(119.60 \%)$ at zero time. While, after 2 days sample No.1 was high (124.28\%), followed by sample No.3 $(110.45 .87 \%)$, sample No. $4(106.52 \%)$ and sample No.2 (102.96\%).

After 4 days sample No.3 was high (99.47\%), followed by sample No.1 (98.45.34\%), sample No. 4 (90.55\%) and sample No.2 (90.32\%).

Table (7): Staling rate $(\%)$ of processed cake samples with different ratios of soaked sweet lupine and chickpea flour.

\begin{tabular}{lccccc}
\hline \multirow{2}{*}{ Staling rate\% } & Control & \multicolumn{4}{c}{ Processed cake using sweet lupine and chickpea flour } \\
& sample & No. (1) & No. (2) & No. (3) & No. (4) \\
\hline Zero time & 151.60 & 136.87 & 119.60 & 148.00 & 129.96 \\
After (2) days & 133.19 & 124.28 & 102.96 & 110.45 & 106.52 \\
After (4) days & 102.83 & 98.34 & 90.32 & 99.47 & 90.55 \\
\hline
\end{tabular}

No.(1): $20 \%$ soaked sweet lupine flour

No. (2): $20 \%$ chickpea flour

No. (3): 10\% soaked chickpea flour

No. (4): $10 \%$ soaked sweet lupine flour $+10 \%$ soaked chickpea flour

Staling rate \% of sample No.1 was higher than staling rate $\%$ of sample No.2, because sample No.1 contained $20 \%$ soaked sweet lupine which have high amount of phenolic compounds especially, syringic $(47233.88 \mathrm{mg} / 100 \mathrm{~g})$, catechol (3947.36 mg/100 g),benzoic (2098.69 mg/100g), salycilic (2005.46 $\mathrm{mg} / 100 \mathrm{~g})$ and epicatechein $(1753.33 \mathrm{mg} / 100 \mathrm{~g})$. While samples No.2 contained $20 \%$ soaked chickpea flour which have low amount of phenolic compounds especially, catechol (431.05 mg/100 g), benzoic (271.53 $\mathrm{mg} / 100 \mathrm{~g})$, salycili $(162.94 \mathrm{mg} / 100 \mathrm{~g})$ and epicatechein (862.56mg/100g).(Table 3)

Generally, this study revealed that the replacement of wheat flour with soaked sweet lupine and chickpea flour at different levels during processing cakes decreased the freshness period of processed cakes.

\section{REFERENCES}

A.A.C.C. (2002). Approval Methods of American Association of Cereal Chemists, in St. Paul, Minnesota, USA.

AOAC (2000). Association Official Analytical Chemists. Official Methods of Analysis. $7^{\text {th }}$ ed., Washington DC, USA.

Alam, S.O. (2001). Biochemical studies on chickpea (Cicer arietinum L.) utilized in African Food Product. Ph.D. Thesis, Fac. Agric., Cairo Univ., Egypt.

Bourne, M. C.(2003). Food texture and viscosity: Concept and measurement. Elsevier Press, New York/London

El-Hadidy, G.S. (2009). Chemical and biological studies on some hypoglycemic foods. M.Sc.Thesis, Food Technol. Dept., Fac. Agric., Kafrelsheikh Univ., Egypt.

Erbas, M.; Certel M. and Uslu M.K. (2005). Some chemical properties of white lupine seeds (Lupinus albus, L.). J. Food Chem., 89: 341-345.
FAO/STAT (2011). Statistical database. Available at: http:// faostat. fao.org/ site/567 desktopdefault. aspx? page1d1 / 4567\#ancor. Last accessed 28 October.

Goupy, P.; Hugues, M.; Biovin, P. and Amiot, M. J. (1999). Antioxidant composition and activity of barley (Hordeum vulgare) and malt extracts and of isolated phenolic compounds. J. Sci. Food Agric., 79: 1625-1634.

Gulewicz, P .; Martinez-Villaluenga C.; Frias J.; Ciesiolka D.; Gulewicz K. and Viadalval-Verde C. (2008). Effect of germination on protein fraction composition of different lupine seeds. Food Chemistry, 107: 830-844.

Ho, C. T.; Ches, Q.; Shi, H.; Zhang, K. Q and Rosen. R. T.(1992). Antioxidative effect of poly phenol extract prepared from various Chinese teas.Prev.Med.21,520-525.

James, C.S. (1995). Analytical Chemistry of Foods. Chap. 6, General Food Studies, Firsted., The Alden Press, oxford, UK.

Kanner, J.; Frankel. E.; Granit. R.; German. B and Kinsella. J. K.(1994). Natural antioxidants in grapes and wines. J. Agric. Food Chem.,42:1,6467.

Kitterman, J.S. and Rubenthaler, G.L (1971). Assessing the quality of early generation wheat selection with the micro A.W.R.C. Test Cereal Sci. Today, 16(8): 313-322.

Lattanzio, V.A.; Linsalata, V.S.; Palmieri and Vansmere, Y. (1989). The beneficial efficial effect of citric acid and ascorbic acid on the phenolic browning reaction in stored artichoke (Cynara scolymus, L.) heads. Food Chem., 33: 93-106.

Martinez-Villaluenga, C.; Sironi E.; Vidal-Valverde C. and Duranti M. (2006). Effects of oligosaccharide removing procedure on the protein profiles of lupine seed. European Food Research and Technology, 223: 691-696. 
Marinova, E. M. and Yanishlieva. N. V. (1992). Inhibited oxidation of lipids: Comparison of the antioxidative properties of some hydroxyl derivates of benzoic and cinnamic acids. Fat Sci. Technol.,94,428-432.

Partt, D.E. and Hudson. B. J. (1990). Natural antioxidants not exploited commercially. In Food Antioxidants, Hudson, B. J. F., Ed.; Elsevier: London, p 171-192.

Rahut, B.K.; Hossain S.; Bhuiyan M.H. and Shams-UdDin M. (2012). Study on composite flour cake and palmyra palm incorporated cake. Bangladesh Resarch Publication Journal. Volume 7, Issue 4, pp. 378-385.

Smith, G.C.; Hylnil, Z. and Cater, C.M. (1973). Efficiency protein additive as emulsion stabilizers on frankfurters. J. Food Sci., 38: 849.
Steell, R.G. and Torrie, J.H. (1980). Principles and procedures of statistics. 2 ed. Mc-Grow-Hill, New York, USA, pp.120-150.

Twillman, T.J. and White, P.J. (1988). Influence of monoglyeries on the texture, shelf life and dough reheology of corn tortillas. Cereal Chem., 65(3): 253-257.

Vega, C.R.; Loarca, G. and Oomah, B.D. (2010). Minor components of pulses and their potential impact on human health. Food Res. Int. 43: 461-482.

Yamazaki, W.T. (1953). Alkaline water retention capacity test for the evaluation of cooke baking potentialities of soft winter wheat flour cereal chem..; 33(2): 242-246.

Yousif, M.R. and M.F. Safaa (2014). Supplementation of gluten-free bread with some germinated legumes flour. Journal of American Science, 10(3): 84-93.

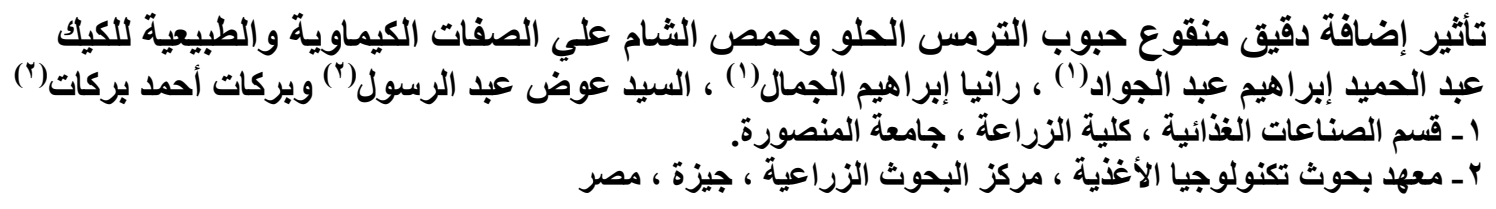

تم تصنع عينات من الكيك باستبدال دقيق القمح بدقيق الحبوب المنقوعـة مـن الترمس الحلو وحمص الثـام بنسب ( ،

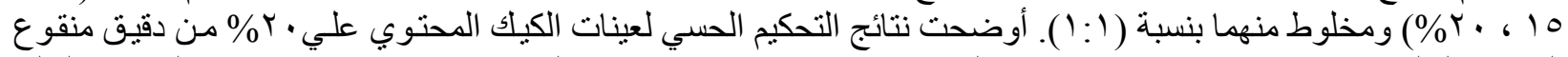

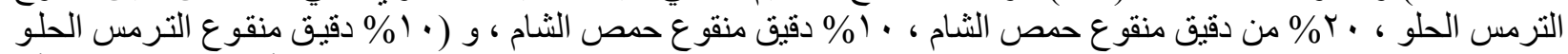

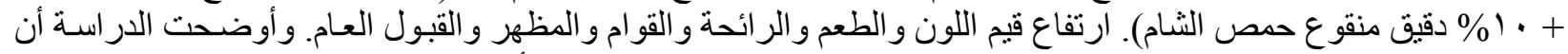

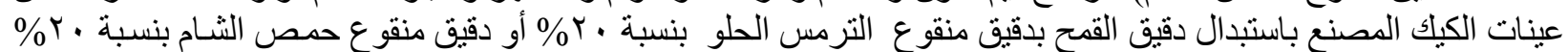

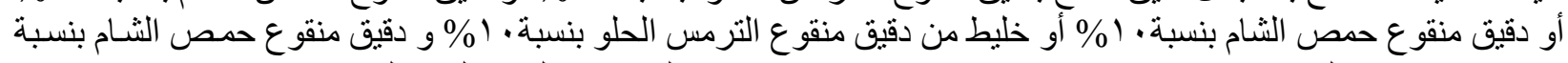

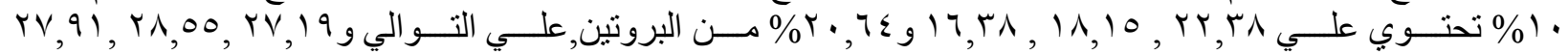

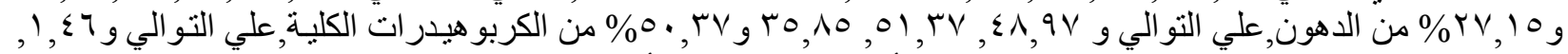

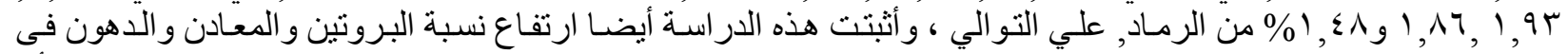

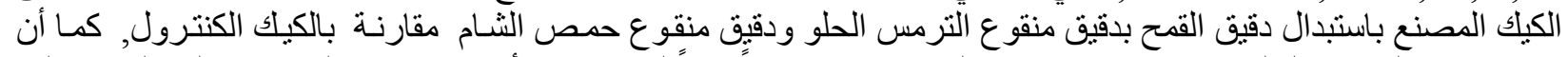

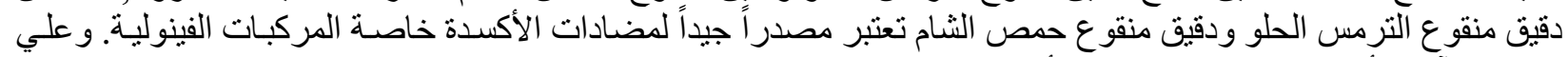

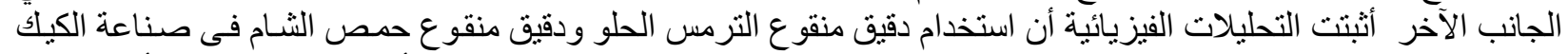

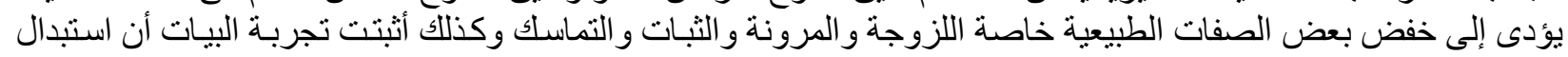

دقيق القمح بدقيق الترمس الحلو المنقوع ودقيق حمص الثقام المنقوع عند صناعة الثنة الكيك يقلل من مدة طز اجة المنتج النهائي. الكلمات الألة: دقيق منقوع الترمس الحلو ، دقيق منقوع حمص الثّام ، الكيك ، القو ام ، مضادات الأكسدة و المركبات الفينولية. 